\title{
A Summary of Properties Used to Evaluate INEEL Calcine Disposal in the Yucca Mountain Repository
}

C. A. Dahl

July 2003

Idaho National Engineering and Environmental Laboratory Bechtel BWXT Idaho, LLC 


\title{
A Summary of Properties Used to Evaluate INEEL Calcine Disposal in the Yucca Mountain Repository
}

\author{
C. A. Dahl
}

July 2003

Idaho National Engineering and Environmental Laboratory Idaho Falls, Idaho 83415

Prepared for the

U.S. Department of Energy

Assistant Secretary for Environmental Management

Under DOE Idaho Operations Office

Contract DE-AC07-99ID13727 


\begin{abstract}
To support evaluations of the direct disposal of Idaho National Engineering and Environmental Laboratory calcines to the repository at Yucca Mountain, an evaluation of the performance of the calcine in the repository environment must be performed. This type of evaluation demonstrates, through computer modeling and analysis, the impact the calcine would have on the ability of the repository to perform its function of containment of materials during the repository lifetime. This report discusses parameters that were used in the scoping evaluation conducted in FY 2003. It provides nominal values for the parameters, with explanation of the source of the values, and how the values were modified for use in repository analysis activities.
\end{abstract}




\section{CONTENTS}

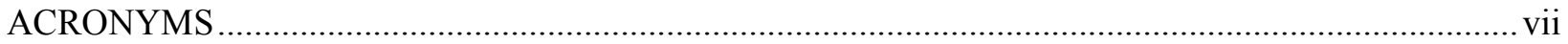

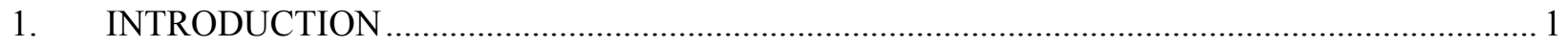

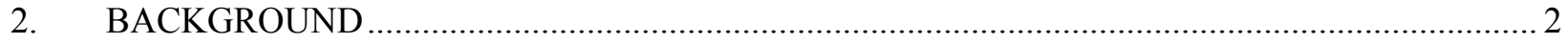

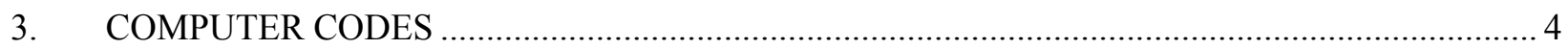

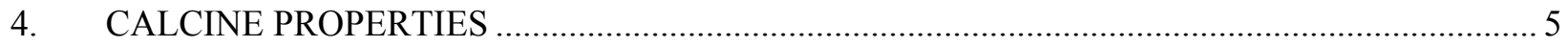

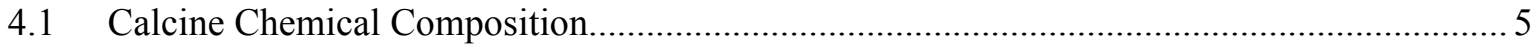

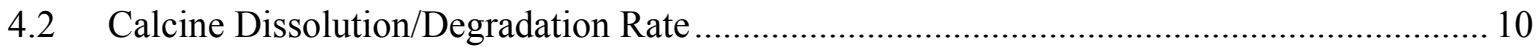

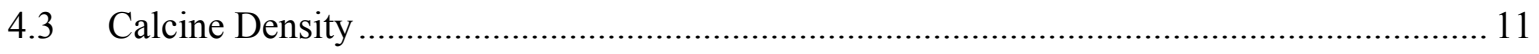

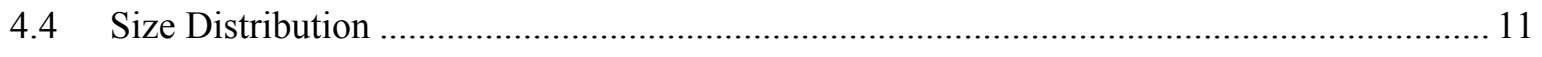

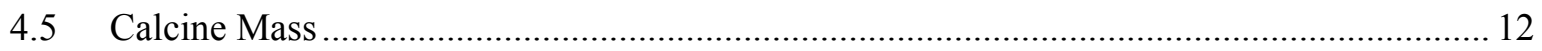

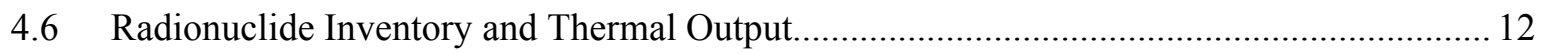

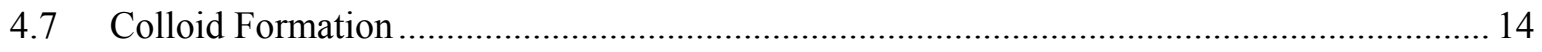

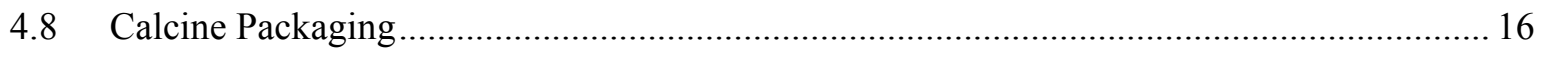

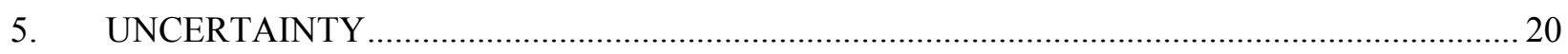

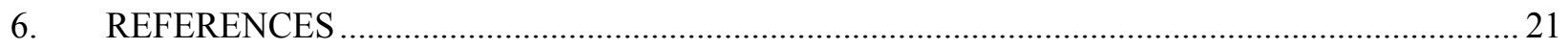

\section{FIGURES}

Figure 1. An illustration of the capacity and inventory of the Calcine Solids Storage Facilities ................ 3

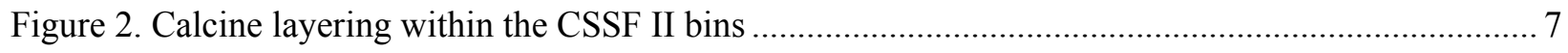

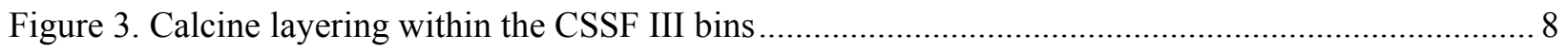

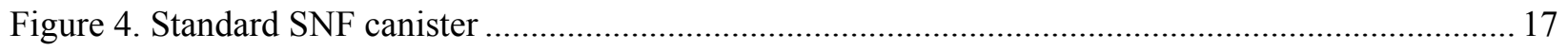

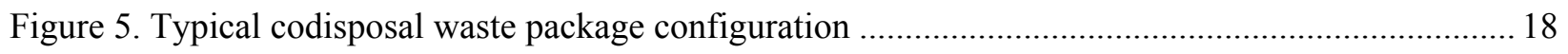




\section{TABLES}

Table 1. Representative chemical composition of INTEC calcined waste ............................................. 6

Table 2. Estimated mass of elements in the Calcine Solid Storage Facilities.......................................... 9

Table 3. Radionuclide content of the Calcine Solids Storage Facilities decayed to January 2032 ............. 13 


\section{ACRONYMS}

CSSF Calcine Solids Storage Facility

DOE U.S. Department of Energy

HPM Historical Process Model

HLW high-level waste

INEEL Idaho National Engineering and Environmental Laboratory

INTEC Idaho Nuclear Technology and Engineering Center

SNF spent nuclear fuel

TSPA Total System Performance Assessment 


\section{A Summary of Properties Used to Evaluate INEEL Calcine Disposal in the Yucca Mountain Repository}

\section{INTRODUCTION}

The Idaho National Engineering and Environmental Laboratory (INEEL) has an inventory of high-level waste (HLW) in the form of calcine. The current planning basis for disposal of the calcine is to process it into a borosilicate glass and dispose of it in the proposed Monitored Geologic Repository at Yucca Mountain, Nevada, in codisposal waste packages with U.S. Department of Energy (DOE) spent nuclear fuel (SNF). The existing evaluations of the HLW performance in the repository were conducted under this basis. ${ }^{1}$ Because of a desire to accelerate cleanup and reduce costs, various alternatives for disposal of materials to the repository are being investigated. One of these alternatives is to dispose of the calcine in the repository without further treatment or minimal treatment to stabilize the material. ${ }^{2}$ This is referred to as direct disposal.

Regulatory requirements specify that the analysis of material placement in the repository be performance based. The term "performance based" means evaluating various parameters, such as radionuclide release, through analysis of the as-packaged material response to the repository environment. This report documents the properties used to evaluate calcine performance in the repository analyses during scoping studies conducted in fiscal year (FY) 2003. It centralizes information from different sources and discusses how the information is transformed to parameters that are used in the analysis of the material in the repository. It also identifies assumptions supporting that information. This report is a living document that will be modified on a yearly basis as more refined data to support repository performance analyses becomes available.

The data in this report will feed two different, related computer-based analyses that are a major part of these evaluations. The first of these, a predictive geochemistry analysis, is used to evaluate changes in the disposal canister and material chemistry due to interactions with the chemicals in the underground and package environment. A specific computer program, EQ3/6, will be used to perform these evaluations. The second, a very complex predictive analysis of radionuclide and material transport through the repository system, known as total system performance assessment (TSPA), will be used to analyze repository performance to contain the materials. In the TSPA, the total repository response for the total set of waste packages in the repository is modeled in the computer program GoldSim. 


\section{BACKGROUND}

Early in nuclear energy development, it was recognized that ${ }^{235} \mathrm{U}$ was a reusable commodity. Typically, reactors burned up only a small percentage of this fissile nuclide in any core fuel load. The remaining mass needed to be separated from fission products so that it could be used to make new fuel. Several facilities were built across the United States to accomplish that recovery. These included the Hanford Site, the Savannah River Site, and the INEEL. At the INEEL, the Idaho Nuclear Technology and Engineering Center (INTEC) was constructed for specialty processing of multiple test reactor SNF types using chemical separations processes similar to those at the other sites. As more and varied reactor types were developed and tested, different types of spent fuel were processed, and the production chemistry of the INTEC processes was modified to accommodate them.

A by-product from processing SNF was the HLW aqueous raffinate stream that resulted from the chemical dissolution and separations activities in the recovery process. During recovery operation, the liquid raffinate was directed to underground, stainless steel storage tanks until it could be treated for final disposal.

A process was developed that transforms this solution into a stable solid that requires less storage space and is chemically neutral. A development program was begun in 1955 to develop a fluidized-bed calcination process, which started operations in 1966. This process was successful in that the liquid waste was significantly reduced in mass and volume by removal of the water. The waste was stabilized into a free flowing granular solid (calcine) that, in theory, could be easily handled by remote pneumatic transport techniques. Calcine operations at INTEC continued until June 2000 when calcining was stopped.

As the calcine was produced from the raffinate, it was stored in bins while the final disposition process was being developed. Seven sets of these bins, known as the Calcine Solids Storage Facility (CSSF) I-VII, were constructed and are illustrated in Figure 1. As shown in the figure, the number and configuration of the bins changed over time. For example, CSSF I contains four bins; CSSF II contains seven. Figure 1 shows the capacity and calcine volume of each CSSF.

The next step for the treatment of this waste was to have been vitrification of the calcine into borosilicate glass logs and ultimate disposal in the nation's planned HLW repository. However, the development and implementation of this last step is costly. As discussed earlier, initiatives to reduce long-term disposal costs are being investigated. Direct disposal of the calcine is one of these initiatives. 

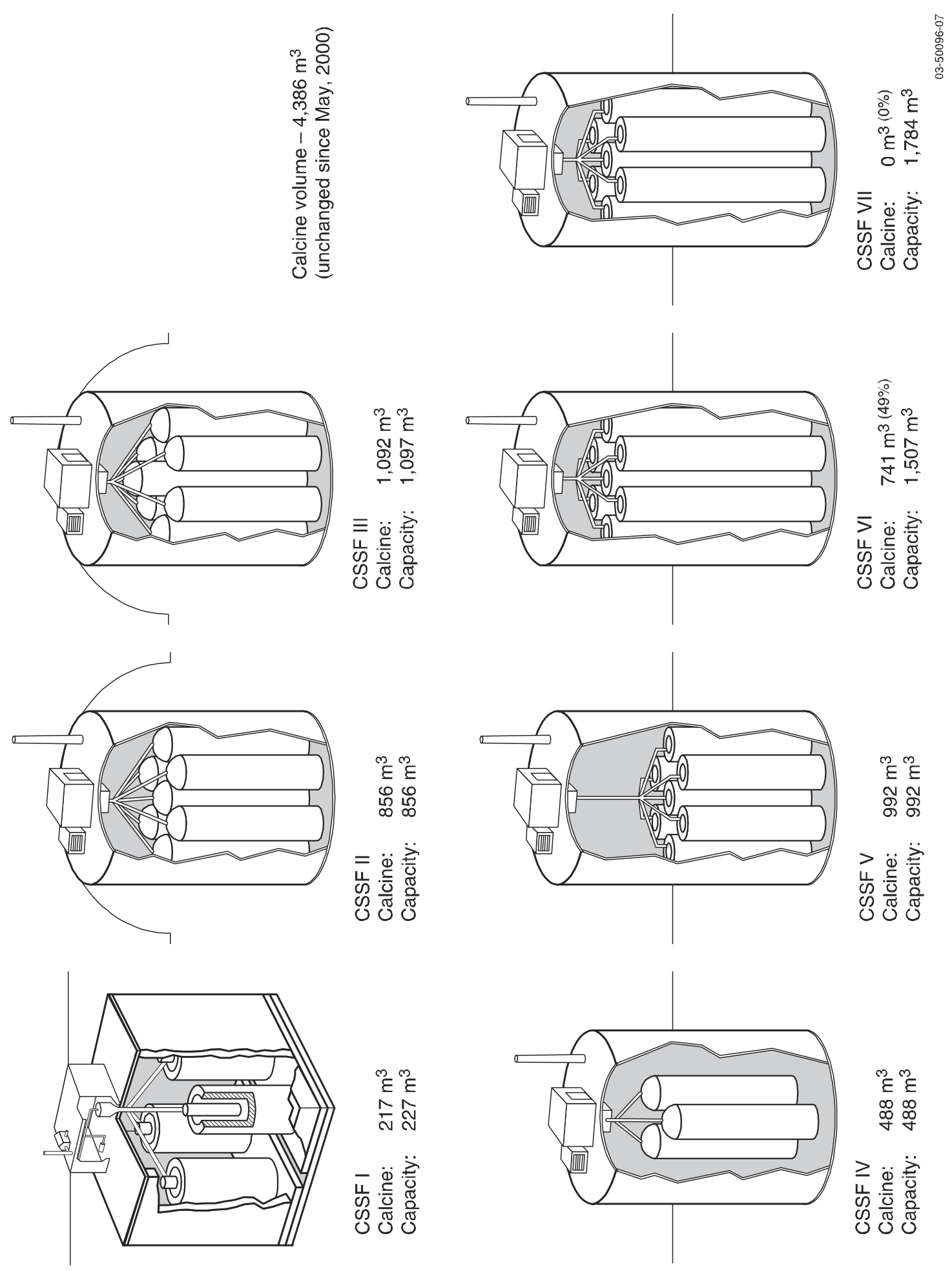

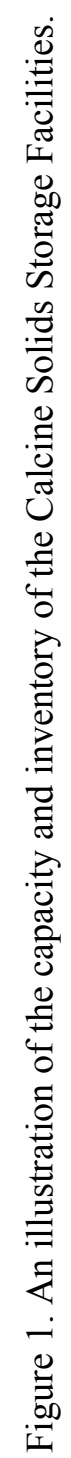




\section{COMPUTER CODES}

All the information in this report was obtained from available references, and none was generated as part of this task. Only commercial software (Microsoft Office 2000) was used in the preparation of this report. 


\section{CALCINE PROPERTIES}

Several properties associated with the calcine are of interest during repository analysis activities. This section addresses each of these properties.

\subsection{Calcine Chemical Composition}

Several types of SNF were processed through INTEC over the years, including SNF with aluminum, stainless steel, and zirconium cladding. Small batch customized processing of low-quantity specialty SNF was done in addition to the major processing in the main processing facility. While the recovery chemistry was generally the same for all the SNF types, the dissolution chemistry to get them into solution, which is the defining part of HLW chemical makeup, differed radically between the types. Processing of the raffinates from these different operations resulted in several types of calcine being produced. It was not feasible to store solutions for long periods of time and mix them for a uniform calcine matrix, because of constraints on storage tank space at INTEC.

At least seven different calcine chemistries resulted, including different calcium to fluorine ratios, different sodium contents, and other chemical differences due to the addition of neutron poisons and other materials required for uranium recovery operations and to preserve the HLW storage tanks from acid attack. Berreth calculated the representative chemical compositions for these calcine products. ${ }^{3}$ These compositions are listed in Table 1, which is reproduced from Reference 3.

As the calcine was formed, it was pneumatically transported into the bins in the CSSFs. A natural consequence of this filling was layering of the calcine material by batch as the bins filled. At various times, portions of a single bin or a series of bins may have filled with a specific calcine. The layering in the CSSFs is illustrated in Figures 2 and 3, which illustrate layering in CSSFs II and III, respectively. This layering can have a significant impact on the properties of a specific amount of calcine. However, in repository analysis studies, including the TSPA modeling, the calcine is evaluated as a whole, so the calcine properties modeled are average values over the entire content. This approach has been used in development of analyses to date at the repository for SNF and borosilicate glass waste. The approach is continued here. Because of this approach, only average properties of the calcine are put into the analyses. If it is suspected that a peak in a particular parameter may impact the results of the analysis, a parametric study is performed to evaluate the impact of that parameter. If a significant impact is found, the value of that parameter in the model may require adjustment.

Staiger has constructed a Historical Process Model (HPM) by using a spreadsheet format that contains extensive information about the calcine based on operating data at the time of calcine generation. ${ }^{a}$ Among other items, the HPM contains estimates of the chemical inventory of each bin of each CSSF. These estimates are totaled and shown in Table 2. Because of the difficulty in assigning specific thermodynamics to each reaction, the values shown in Table 2 are for elements and expected anions, including specific species that were shown to be present by laboratory analysis in the feed stream to the calciner. An update to the HPM is in progress that will estimate the chemical state of each element. Because this information is not required for the FY-03 repository analysis activities, no attempt has been made for this report to estimate the chemical state (oxides, fluorides, etc.) of each element. This information will be incorporated in a future revision of this report to support planned geochemical evaluations.

a. M. D. Staiger, Personal Communication to C. A. Dahl, May 19, 2003. 
Table 1. Representative chemical composition of INTEC calcined waste (Calculated values from Reference 3 based on nominal calciner feed).

\begin{tabular}{|c|c|c|c|c|c|c|c|}
\hline \multirow[b]{3}{*}{ Chemical } & \multicolumn{7}{|c|}{ Calcined Waste (wt\%) } \\
\hline & \multirow[b]{2}{*}{ Alumina } & \multirow{2}{*}{$\begin{array}{c}\text { Stainless } \\
\text { Steel }\end{array}$} & \multirow[b]{2}{*}{ Zirconia } & \multicolumn{2}{|c|}{ Fluorinel } & \multirow{2}{*}{$\begin{array}{c}\text { Zirconia-Na-blend } \\
5: 1\end{array}$} & \multirow{2}{*}{$\begin{array}{l}\text { Fluorinel-Na-blend } \\
\qquad 4.2: 1\end{array}$} \\
\hline & & & & $\mathrm{Ca} / \mathrm{F}=0.55$ & $\mathrm{Ca} / \mathrm{F}=0.7$ & & \\
\hline $\mathrm{Al}_{2} \mathrm{O}_{3}$ & 90.6 & 63 & 14.4 & 7.1 & 6.3 & 14.1 & 9.6 \\
\hline $\mathrm{ZrO}_{2}$ & & & 23.4 & 21.8 & 19.4 & 19 & 17.5 \\
\hline $\mathrm{CaF}_{2}$ & & & 54.3 & 52.7 & 46.9 & 44.4 & 42.4 \\
\hline $\mathrm{B}_{2} \mathrm{O}_{3}$ & 0.06 & 0.6 & 3 & 3.5 & 3 & 2.5 & 2.9 \\
\hline $\mathrm{CdO}$ & & & & 7.1 & 6.4 & & 5.7 \\
\hline $\mathrm{Na}_{2} \mathrm{O}$ & 3.1 & & & & & 4.5 & 5.1 \\
\hline $\mathrm{K}_{2} \mathrm{O}$ & & & & & & 0.9 & 1.1 \\
\hline $\mathrm{CaO}$ & & & 3.9 & 3.8 & 13.5 & 12.8 & 12.2 \\
\hline $\mathrm{Fe}_{2} \mathrm{O}_{3}$ & 0.6 & 9.6 & 0.1 & 0.05 & 0.03 & 0.3 & 0.2 \\
\hline $\mathrm{Hg}$ & 2.9 & & & & & & \\
\hline $\mathrm{SO}_{4}$ & 1.2 & 12.2 & & 2.8 & 2.5 & 0.3 & 2.6 \\
\hline $\mathrm{PO}_{4}$ & & & & & & 0.2 & 0.2 \\
\hline $\mathrm{Cr}_{2} \mathrm{O}_{3}$ & & 1.4 & & & & & \\
\hline $\mathrm{Gd}_{2} \mathrm{O}_{3}$ & & 5.8 & & & & & \\
\hline Other & 1 & 8 & 1 & 1 & 1 & 1 & 1 \\
\hline
\end{tabular}




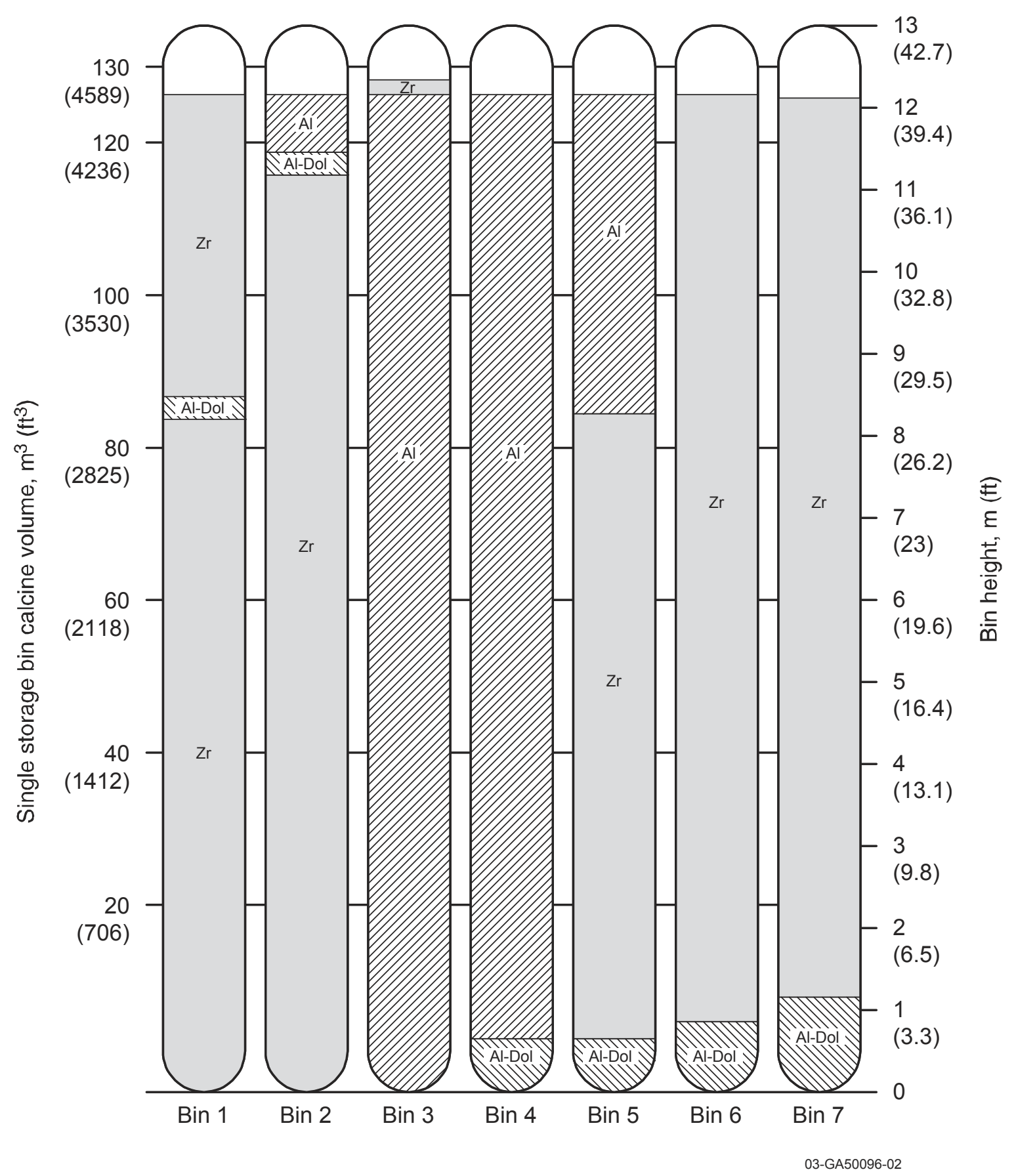

Figure 2. Calcine layering within the CSSF II bins. 


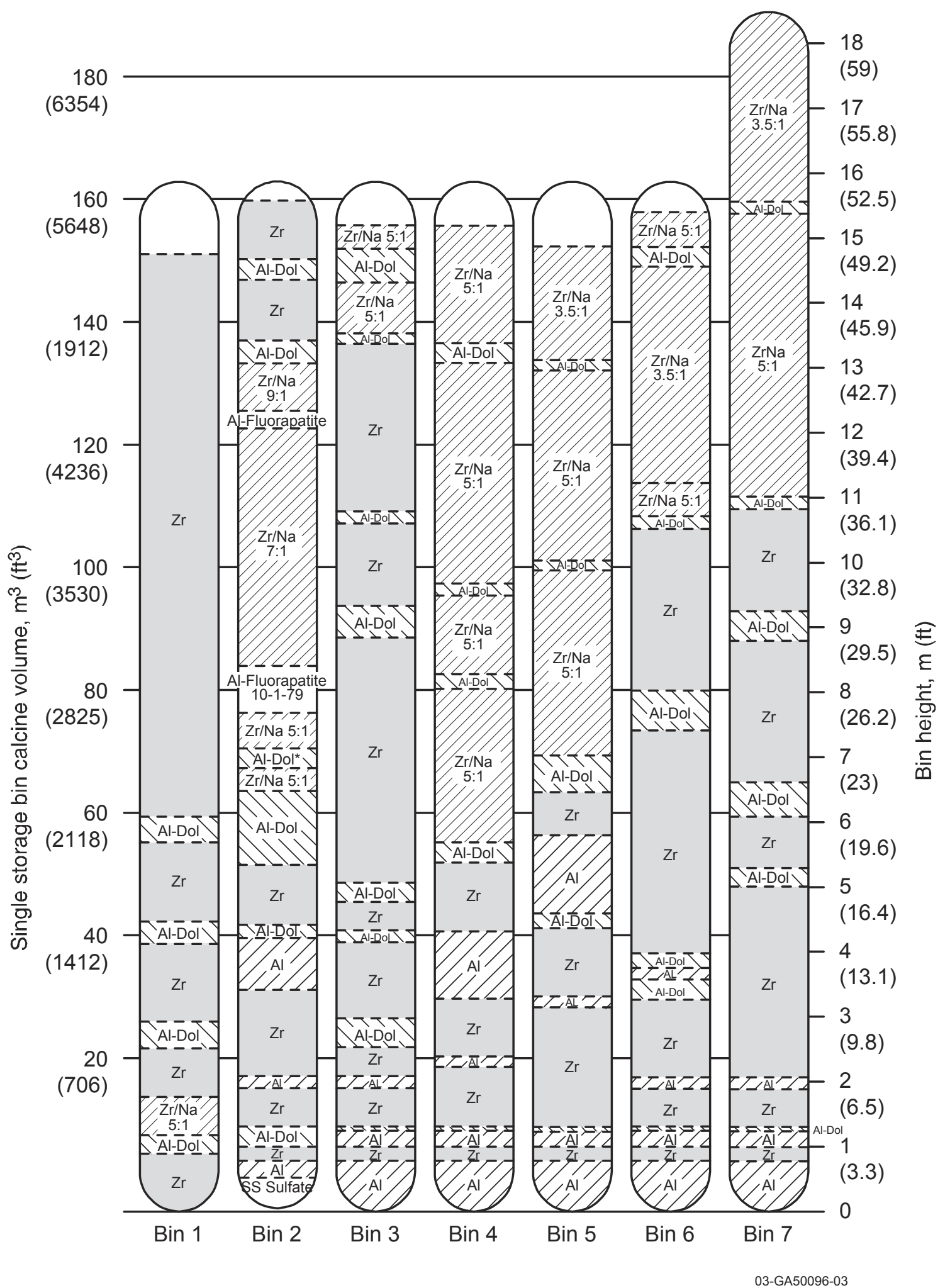

Figure 3. Calcine layering within the CSSF III bins. 
Table 2. Estimated mass of elements in the Calcine Solid Storage Facilities.

\begin{tabular}{|c|c|c|c|c|c|c|c|}
\hline Element & $\begin{array}{c}\text { CSSF } 1 \\
(\mathrm{~kg})\end{array}$ & $\begin{array}{c}\text { CSSF } 2 \\
(\mathrm{~kg})\end{array}$ & $\begin{array}{c}\text { CSSF } 3 \\
(\mathrm{~kg})\end{array}$ & $\begin{array}{c}\text { CSSF } 4 \\
(\mathrm{~kg})\end{array}$ & $\begin{array}{c}\text { CSSF } 5 \\
(\mathrm{~kg})\end{array}$ & $\begin{array}{c}\text { CSSF } 6 \\
(\mathrm{~kg})\end{array}$ & $\begin{array}{l}\text { Total } \\
(\mathrm{kg})\end{array}$ \\
\hline $\mathrm{Al}$ & $8.69 \mathrm{E}+04$ & $2.29 \mathrm{E}+05$ & $1.58 \mathrm{E}+05$ & $6.36 \mathrm{E}+04$ & $1.53 \mathrm{E}+05$ & $2.77 \mathrm{E}+05$ & $9.68 E+05$ \\
\hline B & $4.50 \mathrm{E}+02$ & $6.17 \mathrm{E}+03$ & $1.15 \mathrm{E}+04$ & $5.88 \mathrm{E}+03$ & $1.23 \mathrm{E}+04$ & $4.15 \mathrm{E}+03$ & $4.04 \mathrm{E}+04$ \\
\hline $\mathrm{Ca}$ & & $1.83 \mathrm{E}+05$ & $3.79 \mathrm{E}+05$ & $1.84 \mathrm{E}+05$ & $3.44 \mathrm{E}+05$ & $6.58 \mathrm{E}+04$ & $1.16 E+06$ \\
\hline $\mathrm{Cd}$ & & & & & $4.07 \mathrm{E}+04$ & $6.05 \mathrm{E}+03$ & $4.67 E+04$ \\
\hline $\mathrm{Cr}$ & & $1.54 \mathrm{E}+03$ & $2.88 \mathrm{E}+03$ & $1.59 \mathrm{E}+03$ & $1.54 \mathrm{E}+03$ & $1.17 \mathrm{E}+03$ & $8.72 E+03$ \\
\hline Cs & $5.63 \mathrm{E}+01$ & $1.09 \mathrm{E}+02$ & $1.20 \mathrm{E}+02$ & $6.76 \mathrm{E}+01$ & $1.46 \mathrm{E}+02$ & $4.33 \mathrm{E}+01$ & $5.42 \mathrm{E}+02$ \\
\hline $\mathrm{Fe}$ & $1.54 \mathrm{E}+03$ & $1.39 \mathrm{E}+03$ & $3.40 \mathrm{E}+03$ & $3.55 \mathrm{E}+03$ & $8.08 \mathrm{E}+03$ & $5.80 \mathrm{E}+03$ & $2.37 E+04$ \\
\hline $\mathrm{Hg}$ & $3.43 \mathrm{E}+03$ & $6.97 \mathrm{E}+03$ & $8.07 \mathrm{E}+00$ & $2.97 \mathrm{E}+00$ & $9.45 \mathrm{E}+00$ & $9.86 \mathrm{E}+00$ & $1.04 E+04$ \\
\hline K & & $1.21 \mathrm{E}+03$ & $2.68 \mathrm{E}+03$ & $2.82 \mathrm{E}+03$ & $9.25 \mathrm{E}+03$ & $1.37 \mathrm{E}+04$ & $2.97 E+04$ \\
\hline $\mathrm{Mg}$ & & $5.12 \mathrm{E}+03$ & $1.16 \mathrm{E}+04$ & $2.85 \mathrm{E}+03$ & $9.77 \mathrm{E}+03$ & $5.52 \mathrm{E}+03$ & $3.49 \mathrm{E}+04$ \\
\hline $\mathrm{Mn}$ & & $5.52 \mathrm{E}+02$ & $1.46 \mathrm{E}+03$ & $5.51 \mathrm{E}+02$ & $1.72 \mathrm{E}+03$ & $7.28 \mathrm{E}+02$ & $5.01 E+03$ \\
\hline Mo & $1.01 \mathrm{E}+02$ & $1.80 \mathrm{E}+02$ & $1.85 \mathrm{E}+02$ & $1.04 \mathrm{E}+02$ & $2.23 \mathrm{E}+02$ & $6.64 \mathrm{E}+01$ & $8.60 \mathrm{E}+02$ \\
\hline $\mathrm{Na}$ & $2.41 \mathrm{E}+03$ & $5.13 \mathrm{E}+03$ & $1.35 \mathrm{E}+04$ & $1.16 \mathrm{E}+04$ & $4.59 \mathrm{E}+04$ & $5.51 \mathrm{E}+04$ & $1.34 \mathrm{E}+05$ \\
\hline $\mathrm{Nb}$ & & & & & $2.77 \mathrm{E}+03$ & & $2.77 E+03$ \\
\hline $\mathrm{Nd}$ & $1.27 \mathrm{E}+02$ & $2.25 \mathrm{E}+02$ & $2.30 \mathrm{E}+02$ & $1.30 \mathrm{E}+02$ & $2.77 \mathrm{E}+02$ & $8.30 \mathrm{E}+01$ & $1.07 E+03$ \\
\hline $\mathrm{Nb}$ & & & & & $2.77 \mathrm{E}+03$ & & $2.77 E+03$ \\
\hline $\mathrm{Ni}$ & & $5.69 \mathrm{E}+01$ & $1.69 \mathrm{E}+02$ & $2.50 \mathrm{E}+02$ & $3.31 \mathrm{E}+02$ & $4.23 \mathrm{E}+02$ & $1.23 E+03$ \\
\hline $\mathrm{Sn}$ & & $1.77 \mathrm{E}+03$ & $3.25 \mathrm{E}+03$ & $1.44 \mathrm{E}+03$ & $2.25 \mathrm{E}+03$ & $2.69 \mathrm{E}+02$ & $8.98 \mathrm{E}+03$ \\
\hline $\mathrm{Sr}$ & $1.92 \mathrm{E}+01$ & $1.96 \mathrm{E}+03$ & $3.90 \mathrm{E}+03$ & $1.93 \mathrm{E}+03$ & $3.60 \mathrm{E}+03$ & $2.31 \mathrm{E}+02$ & $1.16 E+04$ \\
\hline $\mathrm{Zr}$ & & $1.11 \mathrm{E}+05$ & $2.05 \mathrm{E}+05$ & $9.09 \mathrm{E}+04$ & $1.42 \mathrm{E}+05$ & $1.70 \mathrm{E}+04$ & $5.67 E+05$ \\
\hline $\mathrm{Cl}$ & & & $5.53 \mathrm{E}+02$ & $7.17 \mathrm{E}+02$ & $1.87 \mathrm{E}+03$ & $1.76 \mathrm{E}+03$ & $4.90 \mathrm{E}+03$ \\
\hline $\mathrm{F}$ & & $1.64 \mathrm{E}+05$ & $2.89 \mathrm{E}+05$ & $1.30 \mathrm{E}+05$ & $2.26 \mathrm{E}+05$ & $2.98 \mathrm{E}+04$ & $8.39 E+05$ \\
\hline $\mathrm{CO}_{3}$ & & $2.01 \mathrm{E}+04$ & $4.70 \mathrm{E}+04$ & $8.48 \mathrm{E}+03$ & $3.81 \mathrm{E}+04$ & $2.68 \mathrm{E}+04$ & $1.41 \mathrm{E}+05$ \\
\hline $\mathrm{NO}_{3}$ & $4.29 \mathrm{E}+03$ & $1.04 \mathrm{E}+04$ & $2.68 \mathrm{E}+04$ & $2.35 \mathrm{E}+04$ & $9.14 \mathrm{E}+04$ & $9.86 \mathrm{E}+04$ & $2.55 \mathrm{E}+05$ \\
\hline $\mathrm{PO}_{4}$ & $1.98 \mathrm{E}+03$ & $2.73 \mathrm{E}+03$ & $1.32 \mathrm{E}+04$ & $6.02 \mathrm{E}+02$ & $2.77 \mathrm{E}+03$ & $1.23 \mathrm{E}+03$ & $2.25 \mathrm{E}+04$ \\
\hline $\mathrm{SO}_{4}$ & $2.54 \mathrm{E}+03$ & $6.25 \mathrm{E}+03$ & $1.16 \mathrm{E}+04$ & $2.87 \mathrm{E}+03$ & $3.19 \mathrm{E}+04$ & $9.63 \mathrm{E}+03$ & $6.48 \mathrm{E}+04$ \\
\hline Trace FP & $6.19 \mathrm{E}+02$ & $1.54 \mathrm{E}+03$ & $1.54 \mathrm{E}+03$ & $8.32 \mathrm{E}+02$ & $1.92 \mathrm{E}+03$ & $1.26 \mathrm{E}+03$ & $7.71 \mathrm{E}+03$ \\
\hline $\mathrm{U}$ & $1.41 \mathrm{E}+01$ & $2.62 \mathrm{E}+01$ & $1.93 \mathrm{E}+01$ & $3.51 \mathrm{E}+01$ & $2.08 \mathrm{E}+02$ & $2.33 \mathrm{E}+02$ & $5.36 \mathrm{E}+02$ \\
\hline $\mathrm{O}$ & $7.73 \mathrm{E}+04$ & $2.42 \mathrm{E}+05$ & $2.29 \mathrm{E}+05$ & $1.05 \mathrm{E}+05$ & $2.18 \mathrm{E}+05$ & $2.59 \mathrm{E}+05$ & $1.13 E+06$ \\
\hline Total & $1.82 \mathrm{E}+05$ & $1.00 \mathrm{E}+06$ & $1.42 \mathrm{E}+06$ & $6.43 \mathrm{E}+05$ & $1.39 \mathrm{E}+06$ & $8.82 \mathrm{E}+05$ & $5.52 \mathrm{E}+06$ \\
\hline
\end{tabular}




\subsection{Calcine Dissolution/Degradation Rate}

The rate at which calcine is expected to degrade or dissolve in groundwater directly affects the rate at which radionuclides and other bound species are released from the matrix into the groundwater for transport.

Stewart published general dissolution rate information for several waste forms, chemicals, and compounds, including calcine and borosilicate glass. ${ }^{4}$ His published values for borosilicate glass dissolution rates range from $10^{-5}$ to $10^{-7} \mathrm{~g} / \mathrm{cc}-\mathrm{d}$. His value for fluid bed calcine (similar to the INEEL calcine) is $0.1 \mathrm{~g} / \mathrm{cc}-\mathrm{d}$, or four to six orders of magnitude larger than the borosilicate glass rates. These comparative numbers indicate very high leach rates for calcine relative to the other waste forms discussed, such as glass or grout.

There have been several leaching studies performed specifically on INEEL calcine, wherein the rates at which various constituents are dissolved and removed from the calcine matrix were measured in either water or acid. McLain and Rhodes indicated that significant fractions of cesium, strontium, and cerium were leached from the calcine by successive batch extractions using a $0.5 \mathrm{M} \mathrm{HNO}_{3}$ in a very short time. ${ }^{5}$ They also indicated that the efficiency of $0.5 \mathrm{M}$ acids (including $\mathrm{HNO}_{3}$ ) was only $7-23 \%$ higher than that of pure water at $25^{\circ} \mathrm{C}$.

Paige indicated that $>95 \%$ of cesium and $33 \%$ of strontium were leached by distilled water at $25^{\circ} \mathrm{C}$ in 100 days. ${ }^{6}$ Similar levels of extraction were seen in 4 days using dilute nitric acid. She further indicated that $90 \%$ steady state leaching levels were reached in 5 and 20 days for cesium and strontium, respectively. This study indicated almost no leaching of the aluminum substrate in the same period.

Berreth performed a review of the INTEC leaching data for calcine constituents in a variety of water and acid solutions (up to 8 molar nitric acid) and concluded that significant fractions of many species, including many radionuclides, leached out of the matrix in significant fractions in less than 100 days of testing. Other species, including components of the calcine chemical matrix, showed very slow dissolution rates in room temperature water and nitric acid (see Reference 3).

Chipman performed leaching tests on INEEL calcines and also measured total mass loss from the calcine in water. ${ }^{7}$ He reported dissolution rates comparable to others. In addition, he observed an interesting behavior concerning the total mass dissolved. The mass loss increased rapidly, reaching values near $50 \%$ after a few days. Then the total mass loss reversed and started to decline as various calcine constituents precipitated back onto the calcine mass. Chemical analysis of the precipitated material indicated different chemical states from the initial calcine. These reactions were thought to be caused by interaction with air in the experiment preparation. Given the long residence time expected for water in a waste package, this may affect calculated transport through the repository by lowering the dissolution and leach rates used. It may also provide a mechanism to lower the estimated release rates of materials from the repository. Sensitivity calculations for this variable are not planned for FY 2003. A further literature search will be conducted for the next revision of this report to determine if others have observed this phenomenon. Appropriate parametric analysis of this parameter will be recommended at that time.

Water expected to contact the materials in the repository are evaluated using a standard water defined at the repository as J-13 well water. This water is named after a supply well on the repository site and is the de facto definition of water expected to contact repository contents. An evaluation of J-13 well water ${ }^{8}$ indicates a nominal acidity $(\mathrm{pH}=7.41)$ with some concentration over contact time due to evaporation and concentration mechanisms. Therefore, the above studies are relevant to the materials as expected to be contacted in the repository. 
No studies have been found to date for leach rate tests longer than 100 days. One needs to take care extrapolating low leach rate data for some materials to the geologic time scales (tens of thousands of years) used in the repository analyses. Therefore, for purposes of this work in FY-2003, and based on the work discussed in this section, instantaneous release of all calcine matrix constituents is assumed. Dissolution and leaching mechanism that take up to a year are insignificant in the millennial context, making the instant dissolution a defendable and conservative assumption. Further literature research into calcine dissolution and leaching is warranted, however, to determine if a slower dissolution and leach rate are defensible. The effect of lower rates could be slower transport of material through the repository system.

This discussion is specific to dissolution of the calcine matrix and does not address solubility of the various radionuclides. For these initial studies, it is assumed that the solubility mechanisms and limits for the various radionuclides are the same as currently defined in the model. This assumption requires reevaluation after the completion of detailed geochemistry analysis of the calcine constituents in the repository.

\subsection{Calcine Density}

Two densities, bulk density and specific calcine density, are used for different purposes in the repository analyses.

- $\quad$ The bulk density is required to determine the waste package loading (i.e., the inventory of calcine, radionuclides, and other constituents in each waste package). Frazee provided calcine density information indicating that the bulk density varies from 1.0 to $1.7 \mathrm{~g} / \mathrm{cc}^{\mathrm{b}}$ and recommended using $1.4 \mathrm{~g} / \mathrm{cc}$ as a good value for the average bulk density. The physical characterization information from Berreth (see Reference 3) is consistent with Frazee's information. The use of this value was reviewed by a group of knowledgeable project personnel with agreement that this value would be used for the FY 2003 work. ${ }^{9}$

- $\quad$ The specific calcine density is needed to determine the specific surface area (i.e., surface area per mass) for dissolution. This parameter is not required for FY 2003 analyses because instantaneous dissolution of the calcine matrix is assumed. However, this parameter is included here for completeness in the event evaluations assuming noninstantaneous dissolution are needed. The specific particle density varied from 2.4 to $2.7 \mathrm{~g} / \mathrm{cc}$ for the calcine particles and from 0.9 to $1.2 \mathrm{~g} / \mathrm{cc}$ for the fines. At the higher density, the radionuclide loading is higher; therefore, a conservative approach using the upper value, $2.7 \mathrm{~g} / \mathrm{cc}$, would be used for the TSPA calculations.

\subsection{Size Distribution}

The calcine particle size distribution is used to determine the surface size distribution for calcine dissolution analysis if one does not assume instantaneous dissolution of the material. This parameter is a support parameter for calculating the surface size distribution. For the present analysis, this is not a required parameter because of the assumption of instantaneous dissolution of the calcine discussed above.

\footnotetext{
${ }^{\mathrm{b}}$ Personal Communication between James P. Adams and Christy Frazee on November 12, 2002.
} 


\subsection{Calcine Mass}

The total calcine mass is indirectly used as a support parameter to determine the source term loading for the calculations.

From the HPM and other documents, the total calcine volume is 4,386 cubic meters (see Reference 10 and Footnotes a and b). Based on the selected average bulk density of $1.4 \mathrm{~g} / \mathrm{cc}$, the total calcine mass is calculated as $6,140,000 \mathrm{~kg}$.

\subsection{Radionuclide Inventory and Thermal Output}

Two types of radionuclide inventories are used in repository calculations. These inventories are used to calculate the source term available for release at different points in the handling of the waste packages.

The free radionuclide inventory is an estimate of the mass of radionuclides that are available for release from the calcine when the packaging is breached. This inventory is immediately available for release, without waiting for the leaching mechanisms to transport them from the calcine matrix. The bound inventory provides an estimate of how many radionuclides may be released from the calcine matrix after the packaging is breached and subsequent to application of leaching and waste form degradation mechanisms.

The free radionuclide inventory is calculated as a fraction of the total available radionuclide inventory. The bound inventory is the amount of material that is not assigned to be a part of the free fraction. The fraction defining the free inventory is an input to the TSPA model. For purposes of the present analysis, the free inventory is assumed to be one. This assumption is a direct consequence of assuming instantaneous dissolution of the calcine matrix discussed previously.

Staigers' HPM (see Reference 10) calculates radionuclide inventory values over time. For purposes of this report, values of the radionuclides have been taken as of January 1, 2032, which is the closest to the expected beginning of the repository regulatory period. A different base is required for preclosure analysis activities, and will be defined in a future revision of this report. The values for the radionuclides of transport concern to calcine disposal are shown in Table 3.

The thermal output is used to determine if the heat generated during repository placement is within the boundaries of the repository design. The HPM lists activity values by radionuclide for the calcine. Evaluation of this data indicates that 5 radionuclides, ${ }^{90} \mathrm{Y},{ }^{90} \mathrm{Sr},{ }^{137} \mathrm{Cs},{ }^{137 \mathrm{~m}} \mathrm{Ba}$, and ${ }^{151} \mathrm{Sm}$, makeup greater than $99 \%$ of the curie activity in the calcine. Using generally accepted activity to heat generation conversion factors for these five nuclides ${ }^{11}$ (with curie content decayed to 2032 as described above) results in an average specific volumetric heat generation rate of $14.4 \mathrm{~W} / \mathrm{m}^{3}$. 


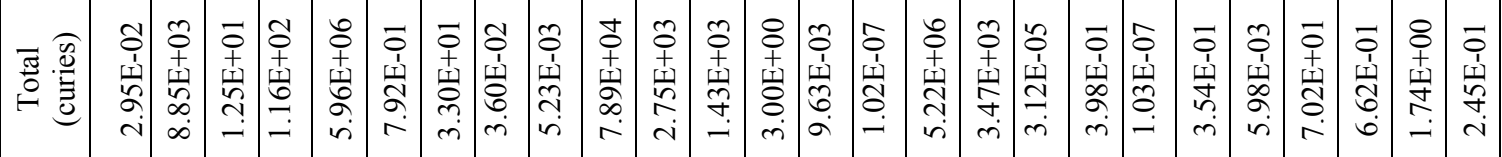

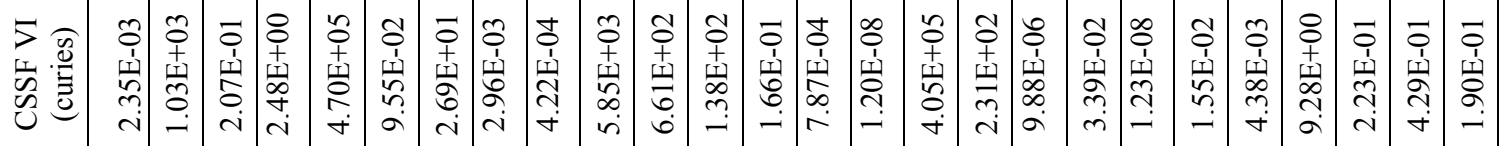

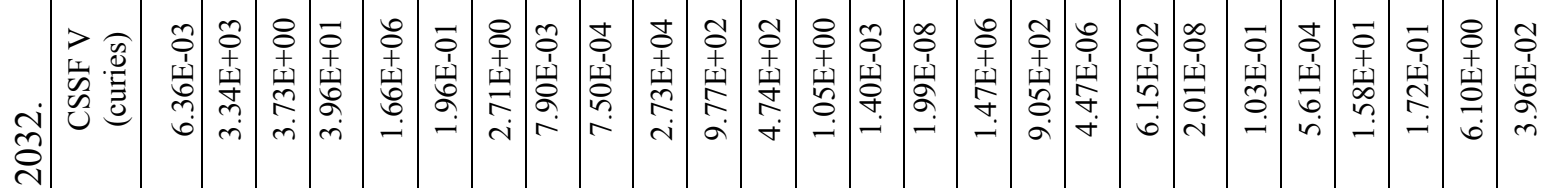

Z鸟

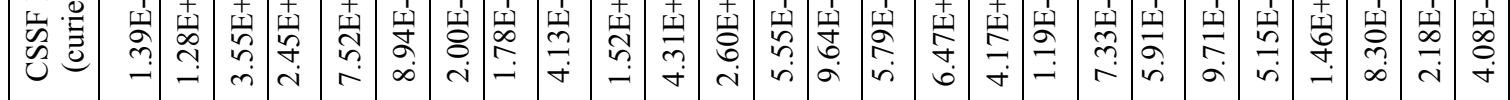

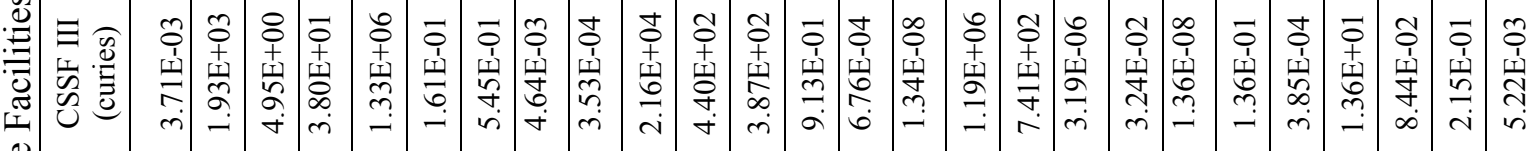

is

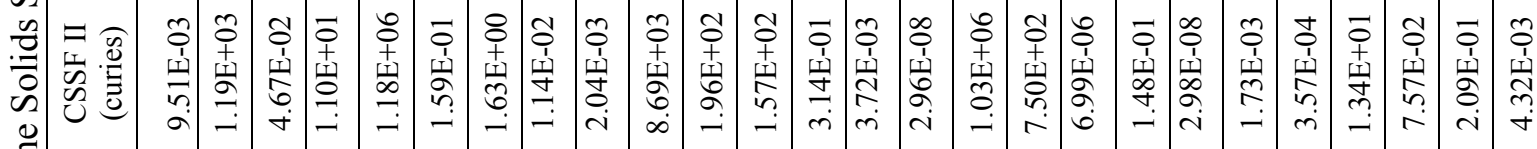

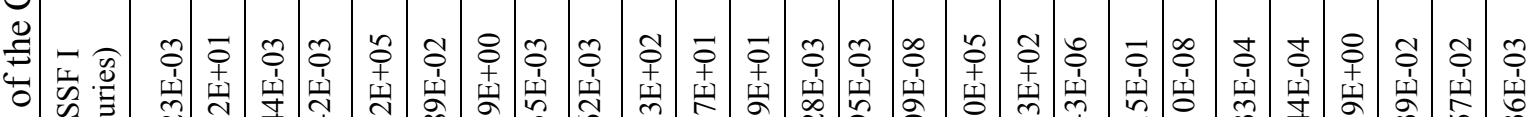

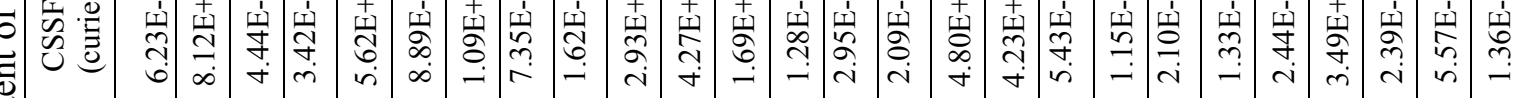

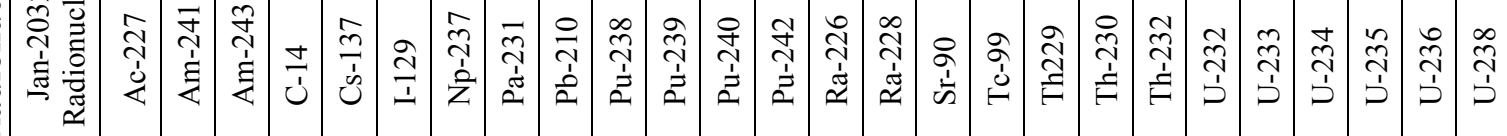

包 


\subsection{Colloid Formation}

The principal transportation mode for most of the radionuclides in the calcine is dissolution in and subsequent transport with the groundwater. However, for some radionuclides, an alternate mode, colloid transport, may dominate.

Colloids are particles with dimensions between $1 \mu \mathrm{m}$ and $1 \eta \mathrm{m}$ in diameter, and they are ubiquitous in natural systems. Colloids consist of the weathered by-products of soils and minerals, hydrolyzed metal precipitates, humic and fulvic acids, and microorganisms. In general, colloids have negatively charged surfaces and are surface active because of their extremely high surface area to volume ratio. Positively charged metal ions, including most radionuclides, readily sorb onto colloids. This increases the concentration of the radionuclide suspended in the aqueous phase and possibly enhances the mobility of a contaminant if the colloid is not attached to a surface or excluded from pore space due to size.

Because colloids remain suspended in the groundwater (because of their small size), they can be transported primarily through cracks in the unsaturated and saturated zones to the biosphere. Radionuclides that are absorbed onto the colloids, such as isotopes of plutonium and americium, are transported with the colloids and ultimately reach the biosphere both earlier and in greater strength than if colloids were not involved.

Colloid formation in the repository has been evaluated. These evaluations involve the SNF and HLW glass packaging codisposal configuration that is discussed in Section 4.8. Even with direct disposal of INEEL calcine, the repository will have SNF and HLW glass present in most waste packages. The calcine addition will be a partial replacement for some of the HLW glass in the system, not a replacement material for all HLW glass.

There are three principal sources of colloids in the repository. First, naturally occurring colloids are present in the groundwater. These colloids result from water erosion of the rocks as the groundwater percolates through the unsaturated zone above the repository. Second, as the HLW glass is dissolved, significant masses of colloids are formed. These colloids can contain radionuclides in the interior of the colloid, away from the surface and thus are not available for either dissolution or sorption onto other surfaces. Third, as the waste package structural materials are corroded, colloids are formed. Radionuclides will typically be absorbed onto either the groundwater or structural material colloids in a reversible manner. Radionuclides that are in the interior of the HLW glass colloids are typically irreversibly absorbed.

A question exists as to whether and to what extent a fourth source of colloids may be introduced into the repository if untreated calcine is placed there. There are two potential colloids sources associated with the calcine. First, when dolomite particles were used as the starting bed material for the calcine process, a significant mass of fines was produced due to attrition of the dolomite. Although most of the mass of these fines is associated with particles that are much larger than typical colloids, a fraction probably is in the correct size range and this could be a significant source of colloids. Second, as the calcine matrix is degraded by the intrusion of groundwater into the waste packages, additional colloids may form in a similar manner to colloids formed by degradation of the HLW glass and waste package structural components.

No information is available for the second potential colloid source, namely formation due to degradation of the calcine matrix. As for the first source, the calcine fines, limited and inconclusive 
experimental information is available. Sifting experiments were conducted on pilot plant calcines, both the calcine particles and fines, to measure the particle size distribution. ${ }^{\mathrm{c}}$ In general, the calcine particles were greater than $100 \mu \mathrm{m}$ in size, which is much larger than colloids. The size distribution for the fines was also measured by using a sonic sifter. These results indicate that the size distribution is dependent on the type of calcine. Zirconium and zirconium/sodium calcine fines tended to be smaller than the other types. Unfortunately, the sonic sifting of this material had a lower screen mesh size sufficient to allow particles as large as 37 microns to pass through them. These results, therefore, are not indicative of whether colloid size particles exist in the calcine.

In the face of this lack of data, an assumption was made that the colloid behavior and generation for this analysis is unchanged from the previous models for HLW glass. A sensitivity study on this parameter will be performed early in the analysis, and a recommendation will be made as to whether the generation of colloids has sufficient influence on the analysis results to recommend an experimental program to determine better parameters for modeling and analysis activities.

c. Personal Communication between James P. Adams and Whitney St. Michael on January 28, 2003. 


\subsection{Calcine Packaging}

Allocation of repository space to DOE SNF and HLW glass is done through mass allocation and has been identified as $10 \%$ of the 70,000 metric tons heavy metal (MTHM) repository total under the Nuclear Waste Policy Act (1982) and its Amendment (1984). Within the 7,000 MTHM allocation, 1/3 of that inventory (or 2,333 MTHM) was to be dedicated to DOE-owned SNF. The balance of the allocation (4,667 MTHM equivalent) will be reserved for defense HLW placement within the repository. ${ }^{12}$

Although there have been changes made to the repository design over the past several years, the current design is based on two fundamentally different representative waste package designs (see Reference 1). The first waste package is designed to accommodate commercial SNF. The spent fuel is not otherwise packaged, and the individual fuel elements are to be inserted into a basket with a rectangular grid of storage locations. This waste package represents five different designs, where the associated parameters (type of SNF, radionuclide loading, etc.) are averaged over the different specific designs.

The second waste package, named a codisposal waste package, is designed to accommodate both HLW and DOE SNF. This waste package is also an average of several different codisposal packages. In the current codisposal waste package design, there will be five slots for borosilicate glass HLW logs surrounding a central slot for a standard canister containing DOE SNF. The standard canister is illustrated in Figure 4, and the codisposal waste package configuration is illustrated in Figure 5. It is anticipated that the calcine will replace the borosilicate glass logs in the five slots in some waste packages, representing the INEEL inventory in the model.

Even though a final decision has not been made as to packaging of the calcine, this analysis will assume that the calcine will be placed into canisters based on the standard SNF canister design. This assumption will be revised, as necessary, when a final decision is made on calcine packaging. In addition, no changes will be made to the SNF characteristics currently in the TSPA model for these calculations. ${ }^{13}$ That is, both the commercial and DOE SNF parameters in the TSPA model will remain unmodified during this study. The characteristics of that part of the HLW, which is expected to be processed into borosilicate glass, will not be modified. Only the characteristics of that portion of the HLW that is to remain as calcine will be modified for this analysis. 


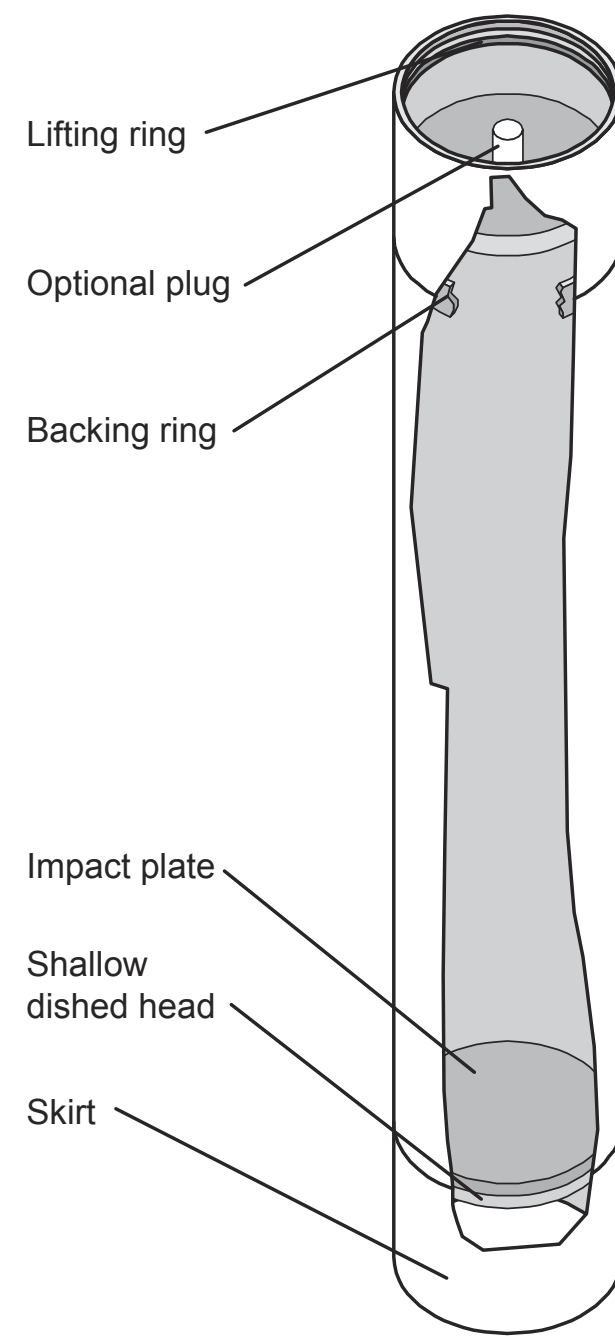

Nominal Outside Diameters: 18 in. and 24 in.

Wall Thickness:

$3 / 8$ in. for 18 in. canister

$1 / 2$ in. for 24 in. canister

Maximum Weight with Fuel: 5,000 to $10,000 \mathrm{lb}$

External Lengths:

Short canister: 118.11 in. Long Canister: 179.92 in.

Material:

Canister Body: SS316 L

03-GA50096-08

Figure 4. Standard SNF canister. For use as a calcine disposal container, this canister would have the Impact Plate removed. 


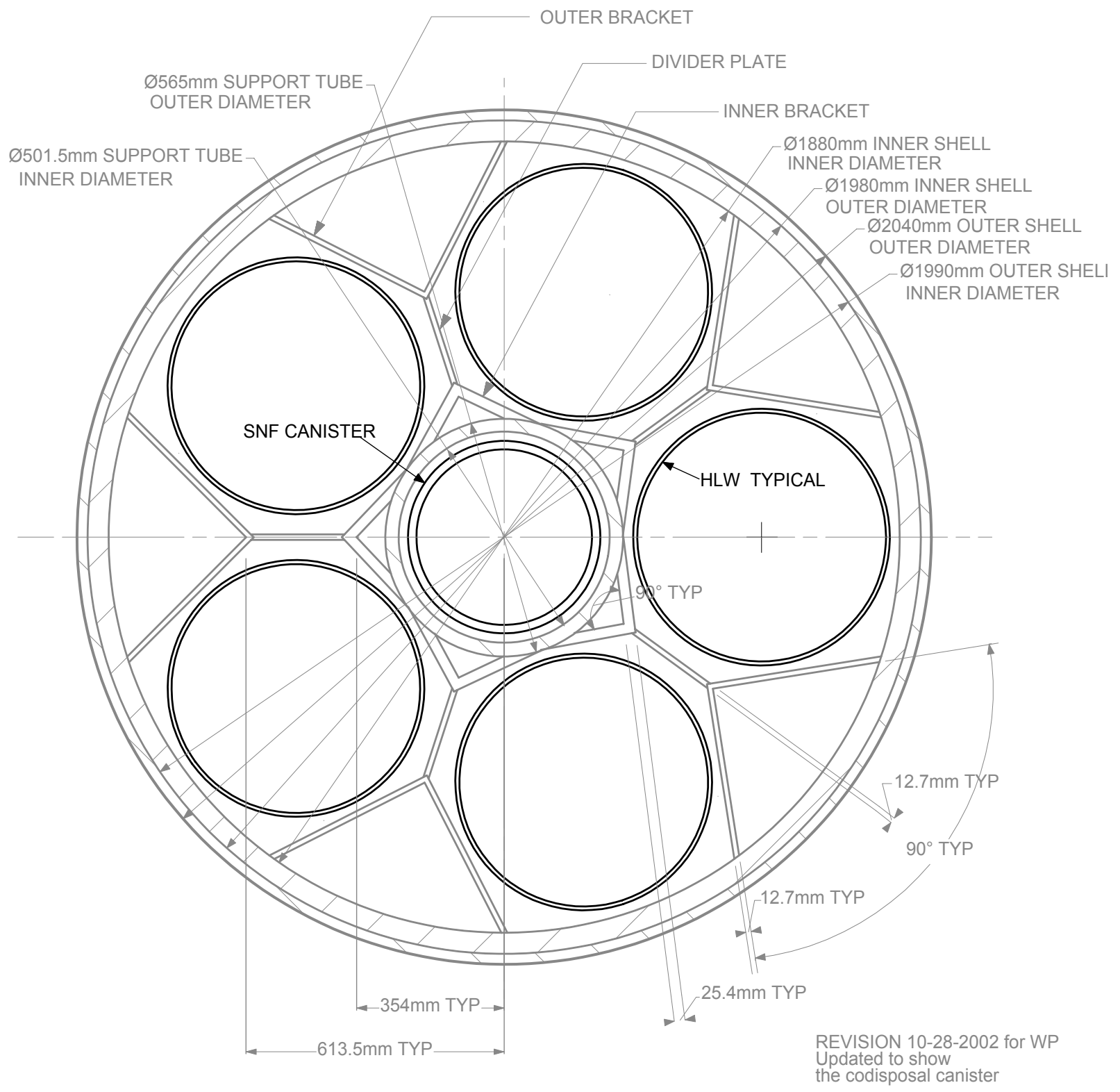

Figure 5. Typical codisposal waste package configuration. 
The DOE SNF will be placed into a standard SNF canister with an approximate diameter of 18 in. $(\sim 450 \mathrm{~mm})$ in both 118.1-in. and 179.9-in. (3,000-mm and 4,570-mm) lengths. In addition, 24 in. $(\sim 610 \mathrm{~mm})$ in both 118.1-in. and 179.9-in. (3,000-mm and 4,570-mm) lengths may also be used if needed for larger size SNF. ${ }^{14}$ Loading of SNF depends on several considerations, including fuel size, configuration, and the potential for inadvertent criticality. None of these considerations are of significance for calcine. So it is assumed that the calcine will be loaded in the largest of these canisters ( 24 in. [610 mm] diameter and $179.9 \mathrm{in}$. [4.570 $\mathrm{mm}$ ] long). It is further assumed that the canister will be filled to capacity and that up to five of these standard canisters will be placed in each waste package.

The total inside volume of the assumed canister is $68,410 \mathrm{in}^{3}\left(1.12 \mathrm{~m}^{3}\right)$. For the purpose of this report, it is assumed that the impact plates will be removed and that the end plate (of the canister) will be welded on prior to filling the canister with calcine. ${ }^{d}$ Then, the calcine will be placed into the canister through a port designed into the end plate. After filling the canister, the port will be plugged. Thus it is assumed that the entire volume of the canister is available to be filled with calcine. Based on a bulk density of $1.4 \mathrm{~g} / \mathrm{cc}\left(1,400 \mathrm{~kg} / \mathrm{m}^{3}\right)$, the total mass of calcine in each canister will be $1,570 \mathrm{~kg}$. If it is assumed five of these standard canisters will fit in each waste package, the total waste package loading (for calcine) will be $7,850 \mathrm{~kg}$. Because there is a total of $6,140,000 \mathrm{~kg}$ of calcine, 783 waste packages will be required for direct disposal.

A conceptual design effort is underway to evaluate using a larger "Super Canister" to contain the calcine and minimize filling/handling operations. This canister would nominally be $66 \mathrm{in}$. (1677 $\mathrm{mm})$ in diameter by 204 in. (5186 mm) long (see Footnote d). Because of its large size, it would hold a much higher volume of calcine $\left(482,087.6 \mathrm{in}^{3}\left[7.9 \mathrm{~m}^{3}\right]\right)$. In addition, a conceptual annular canister design is under evaluation. This design places the calcine in an annulus surrounding an SNF canister. This canister would hold $7.0 \mathrm{~m}^{3}$ of calcine. These designs may impact some TSPA evaluations relative to assumed canister failures during the regulatory period due to the different source terms available when one canister fails. As a part of the conceptual design, many canister configurations are under evaluation, including studies on potential size of the canister. This affects assumptions about the mass and source term available in the canister, making assumptions difficult to defend. Because of the state of flux of the design, inclusion of this canister as a base case assumption is deferred until a more definitive conceptual design is available.

d. Personal Communication between Chris Dahl and Keith Morton, May 29, 2003. 


\section{UNCERTAINTY}

The uncertainties in the parameters discussed in this report require further quantification and analysis prior to the results of these analyses being included in future repository license amendment documentation. Quantification of the uncertainty will be performed as part of future work and included in a future revision of this report. 


\section{REFERENCES}

1. Total System Performance Assessment for the Site Recommendation, TDR-WIS-PA-000001 Rev. 00, ICN 01, December 2000.

2 Environmental Management Performance Management Plan for Accelerating Cleanup of the Idaho National Engineering and Environmental Laboratory, DOE/ID-11006, July, 2002

3. J. R. Berreth, Inventories and Properties of ICPP Calcined High-Level Waste, WINCO-1050, February 1988

4. D. C. Stewart, Data for Radioactive Waste Management and Nuclear Applications, John Wiley \& Sons, New York, 1985.

5. M. E. McLain and D. W. Rhodes, Leaching of Fission Products from Calcined Process Waste, IDO-14440, May 1958.

6. B. E. Paige, Leachability of Alumina Calcine Produced in the Idaho Waste Calcining Facility, IN-1011, July 1966.

7. N. A. Chipman, Leaching Characteristics of Idaho Chemical Processing Plant Calcines, WINCO-1074, February 1990.

8 N. D. Rosenberg, G. E. Gdowski, and K. G. Knauss, "Evaporative Chemical Evolution Of Natural Waters at Yucca Mountain, Nevada," Applied Geochemistry 15 (2001), July 2001, p. 1231-1240.

9 H. H. Loo to M. W. Patterson, "Total System Performance Assessment Base Case Parameters," HHL-01-03, February 13, 2003.

10. M. D. Staiger, Calcine Waste Storage at the Idaho Nuclear Technology and Engineering Center, INEEL/EXT-98-00455, June 1999.

11. Integrated Data Base Report-1996: U.S. Spent Nuclear Fuel and Radioactive Waste Inventories, Projections, and Characteristics, DOE/RW-0006, Rev. 13, Table B-1, December 1997.

12. Memorandum from Daniel Dreyfus to Jill E. Lytle, "Proposed Mix of DOE-Owned High Level Waste and Spent Nuclear Fuel,” November 9, 1995.

13. N. H. Williams, ORD, to J. R. Summerson, ORD, "Contract No. DE-AC08-01RW12101 - Final Letter Report Describing the Performance of Proposed Yucca Mountain Repository for the Final Environmental Impact Statement and Site Suitability Evaluation,” Prof. 09/01.012, September 17, 2001.

14. DOE Spent Nuclear Fuel Information in Support of TSPA-SR, DOE/SNF/REP-047, Rev. 2, February 2002. 